\title{
Effect of ultra-disperse powder in electrode coating on properties of welds in MMA welding
}

\author{
Dmitry P. Il'yaschenko ${ }^{a}$, Dmitry A. Chinakhov ${ }^{a}$, Sergey V. Makarova ${ }^{a}$, Vladimir I. Danilov ${ }^{b}$, \\ Andrey A. Galinsky ${ }^{c}$ and Elena V. Verkhoturova ${ }^{d}$
}

${ }^{a}$ Yurga Institute of Technology National Research Tomsk Polytechnic University, Yurga, Russian Federation

${ }^{b}$ Institute of Strength Physics and Material Science, Siberian Branch, Russian Academy of Sciences, Tomsk, Russian Federation

${ }^{c}$ Tyumen Industrial University, Tyumen, Russian Federation

'Irkutsk National Reseach Techniical University, Irkutsk, Russian Federation

\begin{tabular}{l}
\hline A R T I C L EI N F O \\
\hline Article history: \\
Received 9 July, 2019 \\
Accepted 28 August 2019 \\
Available online \\
28 August 2019 \\
\hline Keywords: \\
Nano-dispersed powders \\
Welding electrodes \\
Mechanical properties \\
Crystallization \\
Modification \\
Microstructure \\
\hline
\end{tabular}

\begin{abstract}
A B S T R A C T
Growth of the volumes of dangerous and critical welded metal structures constructed under low temperatures imposes additional requirements on the mechanical properties of the weld joints, particularly, on the impact resistance of the weld joint and on the stability of its values. It can be achieved by using coated electrodes with ultradisperse powders of alloying elements in the coating. To develop new improved welding materials we need to optimize the systems of weld metal alloying to meet the increasingly stringent requirements to the welding-operational characteristics. Introduction of a complex ultradisperse powder $\left(\mathrm{Al}_{2} \mathrm{O}_{3}, \mathrm{SiO}_{2}, \mathrm{TiO}_{2}, \mathrm{Ni}\right)$ into the electrode coating applied for manual metal-arc welding ensures more stable process of electrode metal fusing and its transfer into the welding bath, improves the performance characteristics of the welded metal.
\end{abstract}

\section{Introduction}

Today, expanding manufacturing of important and critical welded constructions in low temperature conditions has posed additional requirements in respect of mechanical characteristics of welds, in particular, notch toughness of a weld and its stability. Traditionally, these characteristics have been controlled via alloying and modifying. The point of these methods is to ensure certain operational properties with the help of a structure formed in the material by means of introducing chemical elements.

Data provided by Analytical Agency (Electronic resource 2019) demonstrate that in 2018 the output of coated electrodes for manual metal arc (MMA) welding amounted to 90254.2 ton in Russia. The study on materials for welding (Mazur et al, 2014; Lozovoi et al., 2007; Votinova, 2016), available on the market in Russia, first of all, coated electrodes manufactured by domestic and foreign producers, has revealed a basic trend in this industry - improvement of tolerance to failure and operational properties of metal constructions welded in MMA welding, with the cost price kept stable. As a rule, different modifiers, e.g. nano-powders are used for this purpose (Chekanova, 2015; Il'yashenko \& Makarov, 2016). Different methods to introduce modifying powders into a weld metal are suggested (Krushenko \& Fil'kov, 2007; Wang et al., 2008; Sapozhkov \& Burakova, 2016; Sokolov et al., 2011) - spraying in a * Corresponding author.

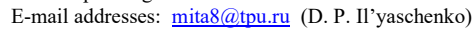


shielding gas (Kuznetsov \& Zernin, 2012), in a fluxing agent via dipping an electrode into a mixture of ultra-disperse materials etc. Introduction of ultra-disperse powder into liquid glass when manufacturing electrodes is the most efficient method. Its efficiency can be attributed to

- minimal losses of a modifying powder;

- stable sanitary and hygienic characteristics of welding process;

- uniform distribution of a modifying powder along the length of an electrode;

- manufacturing technology of electrodes doesn't tend to become more difficult and complicated because of adding technological processes.

We believe that there is currently no integrated approach to determine an appropriate amount of modifying powders to be introduced into an electrode and predict properties of a joint welded in MMA welding with coated electrodes. The study aims at research on the effect of ultra-disperse powder with a complex chemical composition $\mathrm{Al}_{2} \mathrm{O}_{3}, \mathrm{SiO}_{2}, \mathrm{TiO}_{2}$, Ni introduced into cellulose and rutile coating of electrode on operational properties of a joint weld.

\section{Methods of Research}

For experiments electrodes MR-3E (GOST 9466-75) with a diameter of $4 \mathrm{~mm}$ were fabricated according to industrial standards. In the process of fabrication ultra-disperse powders $\mathrm{Al}_{2} \mathrm{O}_{3}, \mathrm{SiO}_{2}, \mathrm{TiO}_{2}$, Ni were introduced into liquid glass (Krushenko \& Fil'kov, 2007). To compare and assess welding and operational properties of experimental electrodes and their industrial analogues MP-3 weld beds were built up on plate surfaces $(09 \Gamma 2 \mathrm{C}, 300 \times 276 \times 20 \mathrm{~mm})$. A weld bed was deposited using a welding rectifier VD-306. Current oscillograms in a welding circuit and voltage of electrode and work piece were registered as energy parameters of weld deposition (Table 1) started changing (Fig. 1).

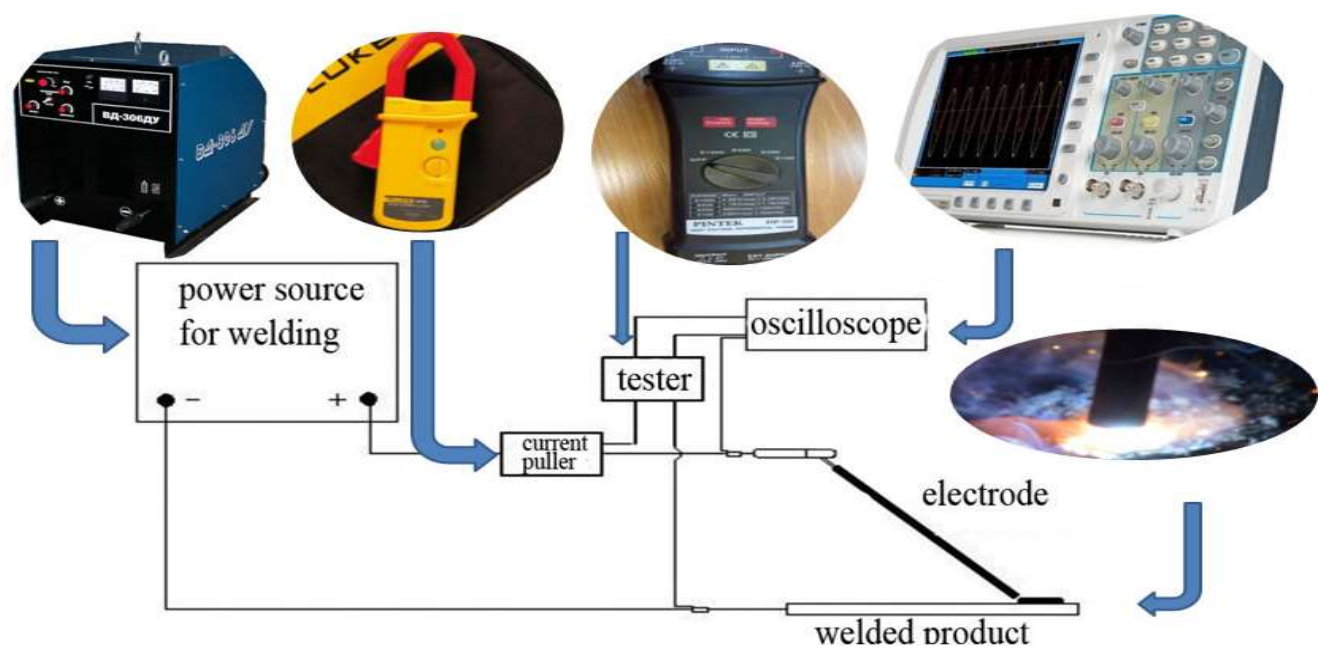

Fig. 1. Experimental procedure to determine stability criteria for MMA welding.

Table 1. Welding conditions for different electrodes and power sources

\begin{tabular}{lll}
\hline Power source & Electrode & Average values of parameters \\
\hline & \multirow{3}{*}{ MR-3 } & Current $113.1 \pm 2.7 \mathrm{~A}$ \\
& & Voltage $243 \pm 0.6 \mathrm{~V}$ \\
Diode rectifier VD-306 & & Welding velocity $0.25 \mathrm{~m} / \mathrm{min}$ \\
& \multirow{3}{*}{ Experimental MR-3E } & Current $110 \mathrm{~A} \pm 2.7$ \\
& & Voltage $24.9 \pm 0.6 \mathrm{~B}$ \\
& & Welding velocity $0.25 \mathrm{~m} / \mathrm{min}$ \\
\hline
\end{tabular}


Arc burning stability of the electrodes under consideration was analyzed via comparing current and voltage oscillograms traced by digital recording oscillograph «АКИП-4122/22»; differential tester «Pintek Electronics «DP-50»; current clamps «Fluke i1010»; software tool «OWON_Oscilloscope». Cross-sections were made on all samples to examine their micro-structure. Cross-sections were made via mechanical smoothing, mechanical polishing with diamond paste ACM 10/7 НВЛ and chemical etching in concentrated $« 75 \% \mathrm{HCl}+25 \% \mathrm{HNO}_{3} »$. Tests were carried out in optic metallography using a microscope Neophot-21, images recorded with a digital camera Genius VileaCam. Mechanical properties of welded metal were assessed according to GOST 6996-66 with the help of universal tension tester ЦДМУ-30, industrial № 2271/55/1 (measurement error 1\%); impact testing machine MК, industrial № 32, (measurement error 3\%). Fractography of welded metal fractures was carried out by an optic microscope Neophot-21, images recorded with a digital camera Genius VileaCam.

\section{Results and Discussion}

Current and voltage oscillograms in MMA welding with different electrodes are shown in Fig. 2. Experimental data on droplet transfer parameters of electrode metal are given in Table 2.
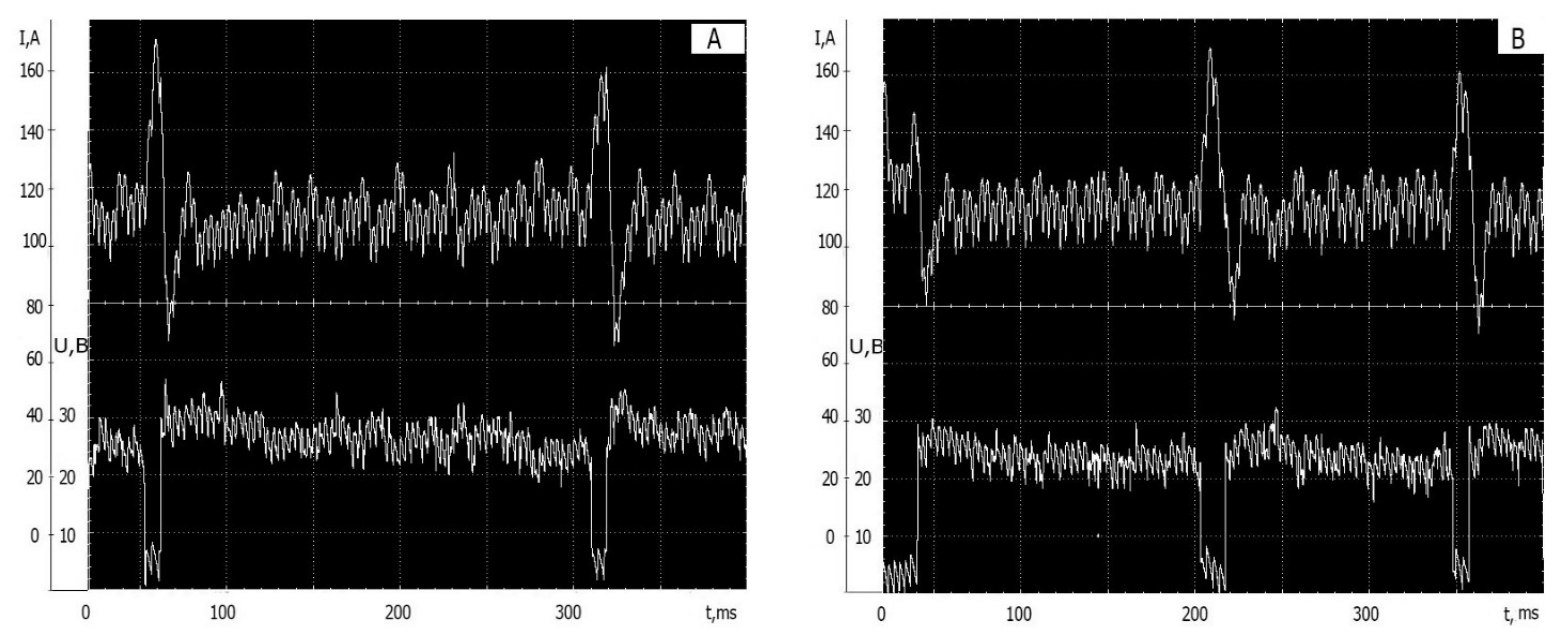

Fig. 2. Current and voltage oscillograms in MMA welding with coated electrodes:

a) MR-3; b) MR-3E

Table 2. Statistical data on parameters of electrode metals droplet transfer

\begin{tabular}{ccc}
\hline \multirow{2}{*}{ Parameter } & \multicolumn{2}{c}{ Electrode } \\
\cline { 2 - 3 } & MR-3 & MR-3E \\
\hline $\begin{array}{c}\text { Arc gap period shortcut } \tau \mathrm{sc}, \mathrm{MS} \pm \text { mean root square } \\
\text { deviation of period shortcut, } \sigma \tau \mathrm{sc}, \text { ms }\end{array}$ & $14.9 \pm 4.6$ & $13.19 \pm 3.9$ \\
$\quad \begin{array}{l}\text { Period of cycle Tsc, Ms } \pm \text { mean root square deviation } \\
\text { of period of cycle } \sigma \text { Tsc, ms }\end{array}$ & $200 \pm 79$ & $177 \pm 64.8$ \\
\hline
\end{tabular}

Data in Table 2 point at decreasing time of droplet transfer and increasing number of shortcuts when using experimental electrodes MP-3 in comparison with standard electrodes MP-3; so, fine-droplet transfer of electrode metal (Makarov et al., 2017; Erohin, 1973) is possible due to modifying powders in electrode coating, which support stability of arc burning (Vaz, Bracarense, 2015; Varnauskas et al., 2004; Lazić et al., 2010). 
Studies (Makarenko et al., 2001; Saraev et al., 2017) suggest that refinement of transferred electrode metal droplets furthers formation of a fine grained weld structure, improves plasticity and notch toughness. Comparative microstructural research on metal welded with different electrodes was carried out as shown in Fig. 3.

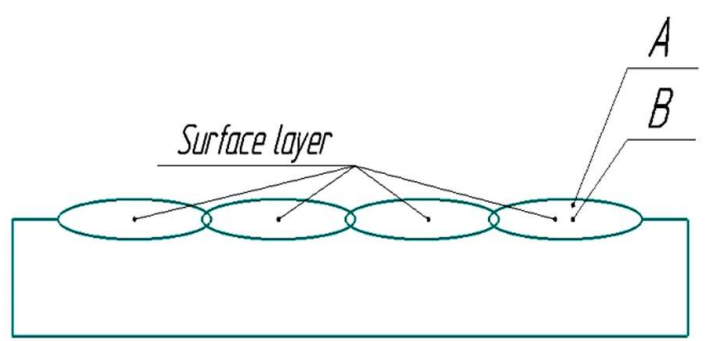

Fig. 3. Study on the surface layer micro-structure: A - upper sub-layer, B - lower sub-layer
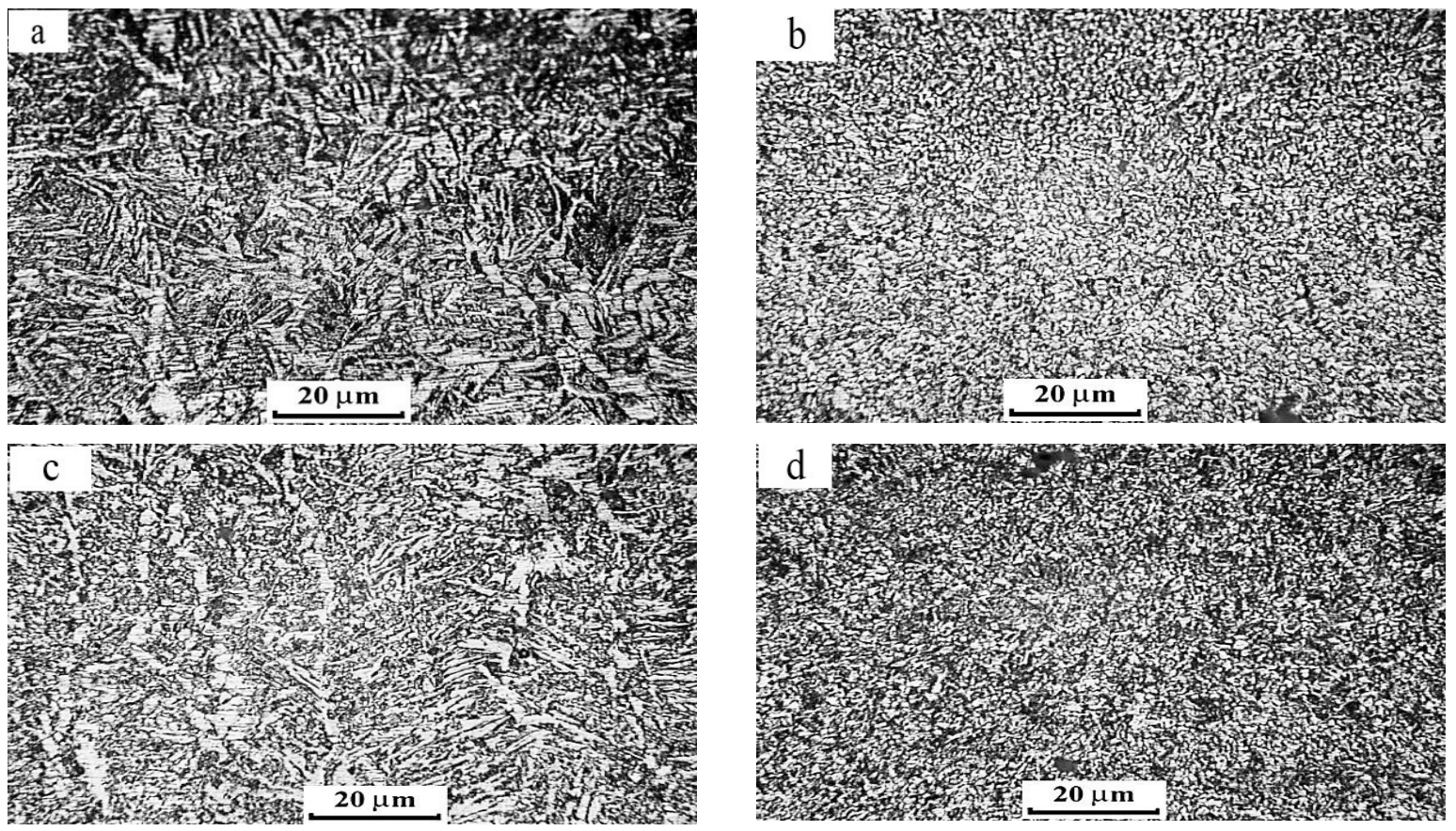

Fig. 4. Images of micro-structure in welded metal: a, b - upper layer (Fig. 3) standard MR-3 and experimental MR-3E, respectively; c, d-lower layer (Fig. 3)

Micro-structural analysis (Fig. 4) has determined

a) layer depth $\approx 1500 \mu \mathrm{m}$. Needle-shaped structure. Mean width and length of needles $\approx 1.8 \pm 0.06 \mu \mathrm{m}$ and $9.0 \pm 0.28 \mu \mathrm{m}$.

b) layer depth $\approx 875 \mu \mathrm{m}$. Ultrafine-grained structure. Average dimension $\approx 1.2 \pm 0.08 \mu \mathrm{m}$.

c) layer depth $\approx 2875 \mu \mathrm{m}$. Branch-shaped structure. «Stem»- a primary ferrite, average cross dimension $\approx 2.8 \pm 0.08 \mu \mathrm{m}$. Average distance between «branches» $\approx 16.0 \pm 0.62 \mu \mathrm{m}$.

d) layer depth $\approx 3125 \mu \mathrm{m}$. Fine-grained structure. Average dimension $\approx 2.4 \pm 0.07 \mu \mathrm{m}$. 
Micro-structures presented demonstrate that introduction of a modifying powder with a complex chemical composition improves micro-structure of welded metal and causes refinement of grains due to ultra-disperse powders in coatings (Kobernik et al., 2015; Boldyrev et al., 2014a; Golovko et al., 2015; Kuznecov, Stepanov, 2015; Boldyrev et al., 2014b; Boldyrev et al., 2012).

Table 3. Mechanical properties of welded metal

\begin{tabular}{lll}
\hline Parameter & Standard electrodes MR-3 & $\begin{array}{l}\text { Experimental electrodes on } \\
\text { a component base MR-3E }\end{array}$ \\
\hline бв, $\mathrm{MPa}$ & $\frac{458 \ldots 464}{461}$ & $\frac{480 \ldots 510}{490}$ \\
$\delta, \%$ & $\frac{17 \ldots 20}{18,5}$ & $\frac{29 \ldots 35}{32}$ \\
\hline $\begin{array}{l}\mathrm{KCU} \text { at }+20^{\circ} \mathrm{C}, \mathrm{J} / \mathrm{cm}^{2} \\
\text { (notch in the center of a weld) }\end{array}$ & $\frac{75 \ldots 85}{80}$ & $\frac{90 \ldots 110}{100}$ \\
\hline
\end{tabular}

Differences found when investigating arc burning stability and analyzing micro-structure of welded metal are important for operational properties of a joint weld. In terms of methods above mechanical properties of welded metal were studied, their findings are given in Table 3. Data obtained (Table 3) show that introduction of ultra-disperse powder with a complex chemical composition into coating of electrode MP-3 results in 10\% increase of ultimate stress limit, $43 \%$ increase of relative elongation, and $20 \%$ rise of notch toughness in comparison with characteristics of standard electrodes. Fractography of samples tested mechanically demonstrate brittle fractures (Fig. 5, 6).
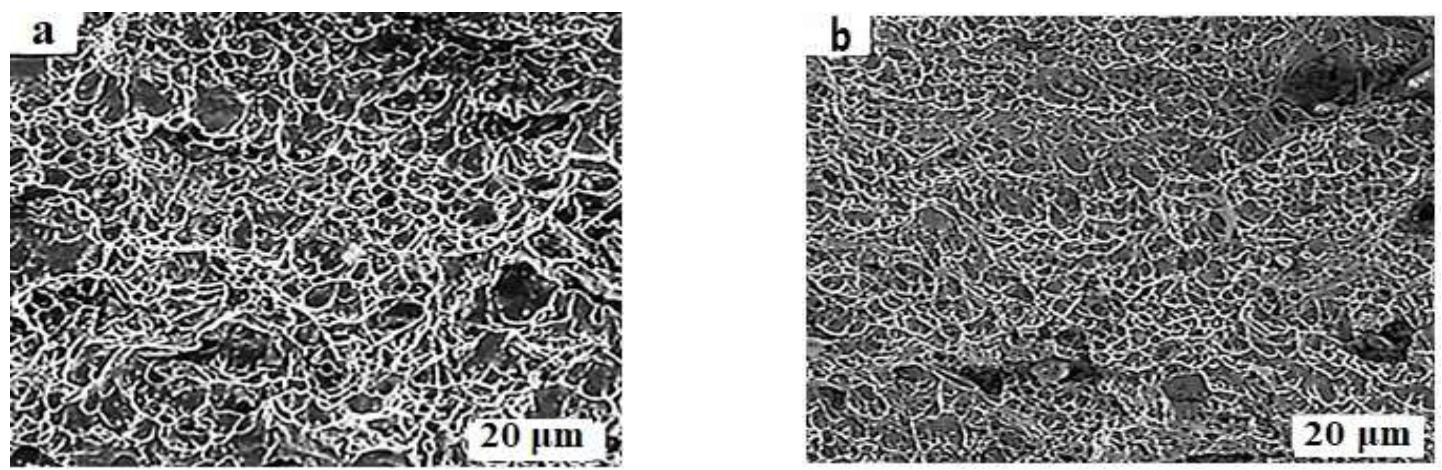

Fig. 5. Micro-photography of soft fracture on the sample surface when viscosity testing: (a) standard electrode MP-3; (b) experimental MP-3.
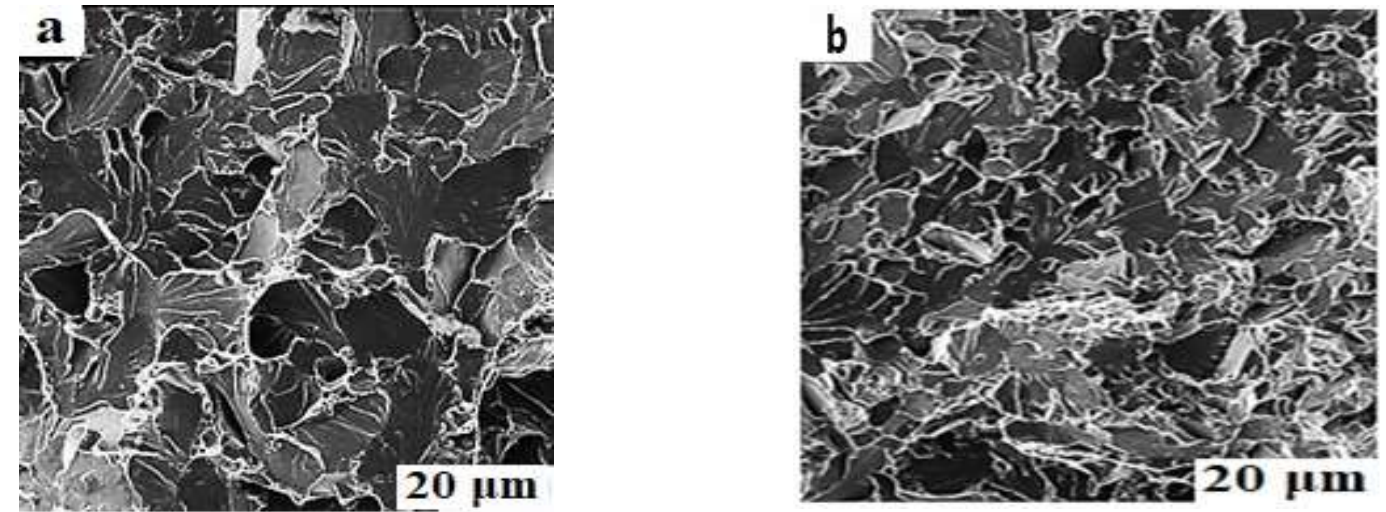

Fig. 6. Micro-photography of brittle fracture on the sample surface when notch toughness testing: (a) standard electrode MR-3; (b) MR-3E. 
Dimensions of fracture facets dominate impact energy. It depends mainly on the package dimension. Size reduction of fracture facets results from formation of needle-shaped ferrite crystallized inside the grain. It was found out that high-peaked grain boundaries decrease concentration and stress intensity at the top of a crack. Furthermore, cracks tend to change their primary direction or split into a number of micro-cracks on the grain boundary with a sufficient crystallographic orientation and stream-like pattern on the fracture surface. Such components of a micro-structure as coarse-grained boundary allotrimorphic ferrite and Widmanstätten ferrite facilitate crack propagation and further brittle fracture.

\section{Conclusions}

Introduction of ultra-disperse modifying powder with a complex chemical composition $\left(\mathrm{Al}_{2} \mathrm{O}_{3}, \mathrm{SiO}_{2}\right.$, $\mathrm{TiO}_{2}, \mathrm{Ni}$ ) into coating of electrodes for MMA arc welding is advantageous over standard electrodes in some aspects:

- stability of melting process and electrode droplet transfer into a weld pool, i.e. $7 \%$ reduction of shortcut period in the arc gap and $12 \%$ decrease of cycle;

- improvement of operational properties of weld metal: $10 \%$ for ultimate stress limit, $43 \%$ relative elongation, and $20 \%$ - notch toughness.

\section{References}

Boldyrev, A.M., Grebenchuk, V.G. \& Gushhin, D.A. (2014a). Effect of titanium dioxide in the composition of the metal-chemical additive on the mechanical properties of the weld metal of steel 10HSND. Welding and Diagnostics, 3, 39-42. In Russian: Boldyrev A.M., Grebenchuk V.G. \& Gushhin D.A. (2014). Vlijanie dioksida titana v sostave metallohimicheskoj prisadki na mehanicheskie svojstva metalla shva stali 10HSND. Svarka I Diagnostika, 3, 39-42.

Boldyrev, A.M. et al. (2014b). Evaluation of thermodynamic factors of the interaction of a metal-chemical additive with a weld pool. Scientific Herald of the Voronezh GASU. Construction and architecture, 2(34), 24-33. In Russian: Boldyrev A.M. i dr. (2014). Ocenka termodinamicheskih faktorov vzaimodejstvija metallohimicheskoj prisadki so svarochnoj vannoj. Nauchnyj vestnik Voronezhskogo GASU. Stroitel'stvo i arhitektura, 2(34), 24-33.

Boldyrev, A.M. et al. (2012). Study of the adhesion strength of particles in the modifying additive for welding submerged-arc structures. Nanotechnologies in construction, 4(2), 56-69. In Russian: Boldyrev A.M. i dr. (2012). Issledovanie prochnosti sceplenija chastic v modificirujushhej prisadke dlja svarki mostovyh konstrukcij pod fljusom. Nanotehnologii v stroitel'stve, 4(2), 56-69.

Chekanova Yu.,V. (2015). New components of welding materials with raw materials of the Kola Peninsula: conditioning, synthesis and interaction: the dissertation ... Candidate of Technical Sciences: 05.16.02 / Chekanova Yuliya Viktorovna; [Place of protection: Institute of Chemistry and Technology of Rare Elements and Mineral Raw Materials named after I.V. Tananaev of the Kola Scientific Center of the Russian Academy of Sciences], Apatity, 157 p. In Russian: Chekanova Ju.V. (2015). Novye komponenty svarochnyh materialov s ispol'zovaniem syr'ja Kol'skogo poluostrova: kondicionirovanie, sintez i vzaimodejstvie: dissertacija ... kandidata tehnicheskih nauk: 05.16.02 / Chekanova Julija Viktorovna; [Mesto zashhity: Institut himii i tehnologii redkih jelementov i mineral'nogo syr'ja im I.V.Tananaeva Kol'skogo nauchnogo centra RAN], Apatity.

Electronic resource (2019): https://alto-group.ru/otchot/marketing/333-rynok-svarochnyx-yelektrodovtekushhaya-situaciya-i-prognoz-2014-2018-gg.html

Erokhin, A.A. (1973). Fundamentals of fusion welding. Physico-chemical patterns. Moscow: Engineering. In Russian: Erohin A.A. (1973). Osnovy svarki plavleniem. Fiziko-himicheskie zakonomernosti. Moskva: Mashinostroenie.

Golovko, V.V. et al. (2015). Distributional features and the role of non-metallic inclusions in weld metal when nanooxides are introduced into a weld pool. Welding and Diagnostics, 6, 25-28. In Russian: 
Golovko V.V. i dr. (2015). Osobennosti raspredelenija i rol' nemetallicheskih vkljuchenij v metalle shva pri vvedenii v svarochnuju vannu nanooksidov. Svarka i Diagnostika, 6, 25-28.

Iljyashchenko, D. P., \& Makarov, S.V. (2016). Production of electrodes for manual arc welding with using the complex modifiers. Applied Nanotechnology: Materials and Applications - New Jersey: Apple Academic Press, 207-211.

Mazur, A.A. et al. (2014). The state and prospects of the world and regional markets of welding materials (review) Automatic welding, 11, 39-45. In Russian: Mazur A.A. i dr. (2014). Sostojanie i perspektivy mirovogo i regional'nyh rynkov svarochnyh materialov (obzor). Avtomaticheskaja svarka, 11, 39-45.

Lozovoi, V.G. et al. (2007). Russian import-replacing electrodes LB-52TRU for welding and repair of main oil and gas pipelines. Welding and diagnostics, 1, 22-23. In Russian: Lozovoj V.G. i dr. (2007). Rossijskie importozamenjajushhie jelektrody LB-52TRU dlja svarki i remonta magistral'nyh neftegazoprovodov. Svarka i diagnostika, 1, 22-23.

Votinova, E.B. (2016). Prediction of the transition of elements to the weld metal in manual arc welding for improving the composition of coatings of welding electrodes: dissertation ... Candidate of Technical Sciences: 05.02.10 / Votinova Ekaterina Borisovna; [Place of protection: Federal State Autonomous Educational Institution of Higher Professional Education "Ural Federal University named after the first President of Russia B. N. Yeltsin"], Yekaterinburg, 131 p. In Russian: Votinova E.B. (2016). Prognozirovanie perehoda jelementov $\mathrm{v}$ naplavlennyj metall pri ruchnoj dugovoj svarke dlja sovershenstvovanija sostava pokrytij svarochnyh jelektrodov: dissertacija ... kandidata tehnicheskih nauk: 05.02.10 / Votinova Ekaterina Borisovna; [Mesto zashhity: Federal'noe gosudarstvennoe avtonomnoe obrazovatel'noe uchrezhdenie vysshego professional'nogo obrazovanija "Ural'skij federal'nyj universitet imeni pervogo Prezidenta Rossii B. N. El'cina"], Ekaterinburg.

Kobernik, N.V. et al. (2015). Modern concepts of modifying the weld metal and weld metal with nano-scale particles (review). Welding and Diagnostics, 5, 13-18. In Russian: Kobernik N.V. i dr. (2015). Sovremennye predstavlenija o modificirovanii naplavlennogo metalla i metalla shva nanorazmernymi chasticami (obzor). Svarka i Diagnostika, 5, 13-18.

Krushenko, G.G., \& Fil'kov, M.N. (2007). Modification of aluminum alloys with nanopowders. Nanotechnology, 12, 58-64. In Russian: Krushenko G.G. \& Fil'kov M.N. (2007). Modificirovanie aljuminievyh splavov nanoporoshkami. Nanotehnika, 12, 58-64.

Kuznecov, V.D., \& Stepanov, D.V. (2015). Structure and properties of the weld metal modified by nanooxides. Automatic welding, 11, 19-24. In Russian: Kuznecov V.D. \& Stepanov D.V. (2015). Struktura i svojstva metalla svarnogo shva, modificirovannogo nanooksidami. Avtomaticheskaja svarka, 11, 19-24.

Kuznetsov, M.A., \& Zernin, E.A. (2012). Nanotechnologies and nanomaterials in welding production (Review). Welding International, 26(4), 311-313. https://doi.org/10.1080/09507116.2011.606158

Lazić, V., Milosavljević, D., Aleksandrović, S., Marinković, P., Bogdanović, G., \& Nedeljković, B. (2010). Carbide Type Influence on Tribological Properties of Hard Faced Steel Layer-Part ITheoretical Considerations. Tribology in Industry, 32(2), 11-20.

Makarenko, V.D. et al. (2001). Technological properties of assembly welding of pipelines. Moscow: LLC Nedra-Business Center. In Russian: Makarenko V.D. i dr (2001). Tehnologicheskie svojstva montazhnoj svarki. Moskva: OOO "Nedra-Biznescentr".

Makarov, S.V., et al. (2017). Distribution of ultrafine powders in liquid glass using a mechano-cavitation unit. Scientific and Technical Bulletin of the Volga region, 1, 46-49. In Russian: Makarov S.V. i dr. (2017). Raspredelenie ul'tradispersnyh poroshkov v zhidkom stekle pri pomoshhi mehanokavitacionnoj ustanovki. Nauchno-tehnicheskij vestnik Povolzh'ja, 1, 46-49.

Sapozhkov, S.B., \& Burakova, E.M. (2016). The Study of Complex (Ti, Zr, Cs) Nanopowder Influencing the Effective Ionization Potential of Arc Discharge When Mma Welding. IOP Conference Series: Materials Science and Engineering, 142(1). DOI:10.1088/1757-899X/142/1/01201

Saraev, Y. N., Chinakhov, D. A., Ilyashchenko, D. I., Kiselev, A. S., \& Gordynets, A. S. (2017). Investigation of the stability of melting and electrode metal transfer in consumable electrode arc welding using power sources with different dynamic characteristics. Welding International, 31(10), 784-790. 
Sokolov, G.N. et al. (2011). Influence of nanodispersed carbides WC and nickel on the structure and properties of weld metal. Welding and Diagnostics, 3, 36-38. In Russian: Sokolov G.N. i dr. Vlijanie nanodispersnyh karbidov WC i nikelja na strukturu i svojstva naplavlennogo metalla. Svarka $i$ diagnostika, 3, 36-38.

Varnauskas, V., Rudzinskas, V., \& Černašejus, O. (2004). Influence of covering components of welding electrodes on chemical composition and mechanical properties of fused metal. Materials Science (Medžiagotyra), 10(1), 7-10.

Vaz, C.T., \& Bracarense, A.Q. (2015). The Effect of the Use of PTFE as a Covered-Electrode Binder on Metal Transfer. Soldagem \& Inspeção, 20(2), 160-170.

Wang, C., Wang, M., Shi, J., Hui, W., \& Dong, H. (2008). Effect of microstructural refinement on the toughness of low carbon martensitic steel. Scripta Materialia, 58(6), 492-495.

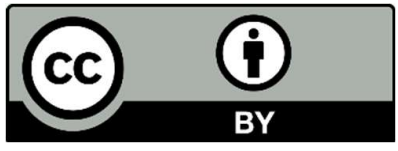

(C) 2020 by the authors; licensee Growing Science, Canada. This is an open access article distributed under the terms and conditions of the Creative Commons Attribution (CC-BY) license (http://creativecommons.org/licenses/by/4.0/). 